\title{
"What Are We?": Latino Politics, Identity, and Memory in the 1983 Chicago Mayoral Election
}

\author{
Jaime Sánchez, Jr iti
}

The 1983 Chicago mayoral election, which polarized Black and white voters, left the nascent Latino electorate in an uncertain position. A reevaluation of this election clarifies the impact of Black mayoral candidate Harold Washington, whose candidacy laid bare significant political divisions and anti-Black sentiment among Latinos as they grappled with their relationship to whiteness. Divisions aside, Washington's effort to court the Latino vote helped legitimate a monolithic, panethnic label in Chicago politics, as evidenced by organizational records, campaign advertising, electoral data, and bilingual media coverage. Reframing the 1983 election as a dual process of race making and panethnic labeling bridges scholarship on Black mayors, Latino politics, and urban history, and questions an enduring political memory of 1983 that has obscured both Latino antiBlackness and the fragility of Latino unity.

"Chicago-from its founding, a city of ethnic politics - has become a city of racial politics. Out of the melting pot, with its generations of immigrants, have come three shades of people-

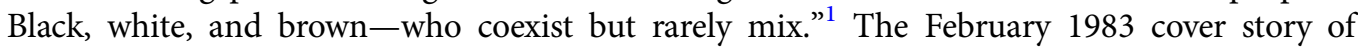
Chicago magazine spoke to the changing tides of race and politics in the Second City. At the time, Chicago was in the midst of an unprecedented mayoral election that promised to be the most serious challenge to the city's political machine in over half a century. The Regular Democratic Organization had long entrenched itself at the helm of City Hall using an expansive system of white ethnic patronage that exchanged jobs and services for votes and power. Chicagoans of color, however, found themselves largely excluded from this tightly managed political rewards system, which depressed their electoral engagement and maintained economic inequality in a heavily segregated urban landscape.

Unlike any other electoral contest before it, the 1983 Chicago mayoral election polarized the city along racial lines. On the one hand, a dramatic political mobilization of Black neighborhoods, boasting tens of thousands of newly registered Black voters, rallied behind the candidacy of U.S. Representative Harold Washington and his anti-machine movement. On the other, the Democratic Machine's white ethnic power-elite channeled their financial and political resources completely against the Black candidate in the primary, and ultimately defected

Sincere thanks to Adam Green, Ramón Gutiérrez, and Susan Gzesh at the University of Chicago, whose mentorship helped bring this project to fruition many years ago. At Princeton University, I would like to thank Alison Isenberg, Kevin Kruse, and Rosina Lozano for their support in refining the manuscript's final iteration. I am also grateful for generative feedback stemming from presentations at the Latina/o Studies Association Conference, the University of Pennsylvania's Andrea Mitchell Center for the Study of Democracy, and the Julian Samora Research Institute at Michigan State University. Last, thank you to Sarah Phillips, the anonymous reviewers, and MAH staff for pushing this piece to the next level.

${ }^{1}$ Andrew Patner, “A Time to Listen: Black and Hispanic Voices Speak Out," Chicago, Feb. 9, 1983, https://www. chicagomag.com/Chicago-Magazine/February-1983/A-Time-to-Listen/ (accessed Aug. 13, 2021).

(C) The Author(s), 2021. Published by Cambridge University Press 
from their party in the general election to support white Republican Bernard Epton. Indeed, the City of Chicago was transformed into a city of racial politics in $1983 .{ }^{2}$ Yet this well-known story in the annals of urban political history leaves much to be discovered about the third "shade" mentioned in the Chicago magazine article. Who were the "brown" Chicagoans, did they even identify as such, and how would they vote?

A series of scholarly works on the role of Latinos in the 1983 election assertively attributes Harold Washington's mayoral victory, in part, to the grassroots mobilization of a nascent Latino voting bloc that embraced a non-white minority identity. ${ }^{3}$ In this article, I make two arguments that complicate the conventional narrative and its presumption of Latino political and racial consciousness. First, the election pushed Chicago's Latino population to grapple significantly with their relationship to whiteness, a process that exposed deep racial divides among Latino ethnic subgroups, and by extension between Latinos and Blacks. Despite these rifts, Washington's campaign successfully advanced the institutionalization of a panethnic Latino category in mainstream political discourse. Together, these arguments contend that the "Latino vote" in 1983 was neither a racial nor political monolith, but rather an imagined constituency fashioned from the top-down by the campaign and Latino political elites. Drawing from campaign records, electoral data, and bilingual media coverage, I offer a re-evaluation of the 1983 election-as well as the first detailed analysis of Latino outreach during the primary campaign - that reveals a foundation of discord in the famed "rainbow coalition."

The 1983 election was a critical inflection point for the political and racial self-fashioning of Chicago's Latino population, which also had to adapt to the shift from ethnic bloc politics to racial politics. As recent work by historian Mike Amezcua demonstrates, Latino Chicago's limited relationship to the Democratic Machine during the 1960s and 1970s was defined by a national-origin, ethnic-politics approach characteristic of white immigrant groups in which "[Mayor Richard J.] Daley and his Amigos created a mutually beneficial relationship rooted in political favors and symbolic gestures of exchange." ${ }^{4}$ Mexican American political and business elites of the Daley era helped maintain the dominance of the white-controlled machine and quelled the impact of growing racial-cultural nationalism. This holding pattern, however, could not last long given the rise of radical social movements led by young Puerto Rican and Mexican activists, increasing voter registration, and a simmering resentment among Latinos over the diminishing returns of ethnic machine patronage.

\footnotetext{
${ }^{2}$ For more on the dominance of the racial issue in the 1983 election and Harold Washington's campaign, see Florence Hamlish Levinsohn, Harold Washington: A Political Biography (Chicago, 1983); Dianne M. Pinderhughes, "An Examination of Chicago Politics for Evidence of Political Incorporation and Representation," in Racial Politics in American Cities, 2nd ed., eds. Rufus P. Browning, Dale Rogers Marshall, and David H. Tabb (White Plains, NY, 1997), 117-35; Gary Rivlin, Fire on the Prairie: Chicago's Harold Washington and the Politics of Race (New York, 1992); and Dempsey J. Travis, "Harold," The People's Mayor: An Authorized Biography of Mayor Harold Washington (Chicago, 1989).

${ }^{3}$ David A. Badillo, "From La Lucha to Latino: Ethnic Change, Political Identity, and Civil Rights in Chicago," in La Causa: Civil Rights, Social Justice and the Struggle for Equality in the Midwest, ed. Gilberto Cárdenas (Houston, 2004), 37-53; Roger Biles, Mayor Harold Washington: Champion of Race and Reform in Chicago (Champaign, IL, 2018), 44-80; Teresa Córdova, "Harold Washington and the Rise of Latino Electoral Politics in Chicago, 19821987," in Chicano Politics and Society in the Late Twentieth Century, ed. David Montejano (Austin, 1999), 3157; Andrew J. Diamond, Chicago on the Make: Power and Inequality in a Modern City (Berkeley, CA, 2017), 249-52; Jaime Dominguez, "Latinos in Chicago: A Strategy Towards Political Empowerment (1975-2003)" (Ph.D. diss., University of Illinois at Chicago, 2007); Gordon Mantler, "Rainbow Reformers: Black-Brown Activism and the Election of Harold Washington," in Civil Rights and Beyond: African American and Latino/a Activism in the Twentieth-Century United States, ed. Brian D. Behnken (Athens, GA, 2016), 217-40; Frederick Douglass Opie, Upsetting the Apple Cart: Black-Latino Coalitions in New York City from Protest to Public Office (New York, 2015), 129-58.

${ }^{4}$ Mike Amezcua, “A Machine in the Barrio: Chicago's Conservative Colonia and the Remaking of Latino Politics in the 1960s and 1970s," The Sixties 12, no. 1 (2019): 95-120, here 97.
} 
But a race-based Latino political consciousness was not universally accepted, nor did it easily transfer into formal electoral politics. Lilia Fernández points to a dramatic transition of Latino racial self-identification evidenced by the 1980 U.S. Census. "Many had concluded that 'white' was not the racial identity they had been assigned in the local social order," Fernández argues, "nor one they wished to claim." Equally telling, however, is that 45 percent of Chicago's "Spanish origin" population still considered themselves racially white. ${ }^{6}$ Latino racial identity in the 1980s was very much in flux, and a pervasive rhetoric of racial resource competition and a supposed Black takeover of City Hall heavily influenced Latino political decision making. This election bore witness to the intense growing pains of Latino racial consciousness and the Washington campaign's effort to inoculate Latinos against a potent strain of anti-Black racism. As such, Latino support for, and opposition against, Harold Washington laid bare intra-ethnic divisions between and within Latino subgroups, stratified by their distinct racial self-positioning at the ballot box.

Harold Washington's campaign for mayor not only urged Mexicans and Puerto Ricans to view themselves as non-white racial minorities, but also actively categorized them as a unified ethnic group. It was clear to Washington and his allies that appealing to a panethnic Latino constituency was the most efficient way to mobilize the ethnically heterogeneous and geographically fragmented Latino neighborhoods. Archival evidence from the campaign's Latino Operations Department reveals the intentional use of bold, panethnic rhetoric and symbolism that prompted voters to reorient their identities beyond their national origins and toward a panethnic Latino label (Figure 1). The Washington campaign courted this broad constituency by flying in national Latino leaders for endorsements and investing in Spanish-language advertising that explicitly spoke to the "Latino" voter. I argue that this strategy brought the panethnic political rhetoric characteristic of presidential elections to the local level and helps merge the local and national scales together in the historiography of the "Latino vote."

More generally, Washington's candidacy fundamentally accelerated the development and legitimation of "Latino" as a mainstream social category. Early works on Latino panethnicity, such as Felix Padilla's foundational 1985 study, Latino Ethnic Consciousness, emphasized the social pressures and cultural similarities that led Latin American immigrants and their U.S.-born descendants to adopt a common identity across nationalities. However, my research findings align more closely with the work of Arlene Dávila and Cristina Mora, who argue that a combination of external actors, including the nation-state, business, media, activists, and bureaucrats, played a more central role in the institutionalization and imposition of the

\footnotetext{
${ }^{5}$ Lilia Fernández, Brown in the Windy City: Mexicans and Puerto Ricans in Postwar Chicago (Chicago, 2012 ), 7.

${ }^{6}$ U.S. Department of Commerce, Bureau of the Census, "Table 70: Total Persons and Spanish Origin Persons by Type of Spanish Origin, Race, and Sex, for Areas and Places: 1980,” in 1980 Census of Population, vol. 1, ch. B, pt. 1 (Washington, DC, 1983), 278.

${ }^{7}$ For recent works on the history of panethnic Latino politics, see Cristina Beltrán, The Trouble with Unity: Latino Politics and the Creation of Identity (Oxford, UK, 2010); Geraldo L. Cadava, The Hispanic Republican: The Shaping of an American Political Identity, from Nixon to Trump (New York, 2020); Eduardo Contreras, Latinos and the Liberal City: Politics and Protest in San Francisco (Philadelphia, 2019); Benjamin Francis-Fallon, The Rise of the Latino Vote: A History (Cambridge, MA, 2019); and Rosina Lozano, An American Language: The History of Spanish in the United States (Oakland, 2018). Studies on panethnic politics build upon previous political histories focused on just one Latino ethnic subgroup. For instance, see Kenneth C. Burt, "The Power of a Mobilized Citizenry and Coalition Politics: The 1949 Election of Edward R. Roybal to the Los Angeles City Council," Southern California Quarterly 85, no. 4 (Dec. 2003): 413-38; Ignacio M. García, Viva Kennedy: Mexican Americans in Search of Camelot (College Station, TX, 2000); Phillip B. Gonzales, Política: Nuevomexicanos and American Political Incorporation, 1821-1910 (Lincoln, NE, 2016); Michelle Hall Kells, Vicente Ximenes, LBJ's Great Society, and Mexican American Civil Rights Rhetoric (Carbondale, IL, 2018); Juan A. Sepúlveda, Jr., The Life and Times of Willie Velásquez: Su Voto es Su Voz (Houston, TX, 2003); Lorrin Thomas, Puerto Rican Citizen: History and Political Identity in Twentieth Century New York City (Chicago, 2010); and María de los Angeles Torres, In the Land of Mirrors: Cuban Exile Politics in the United States (Ann Arbor, MI, 1999).
} 


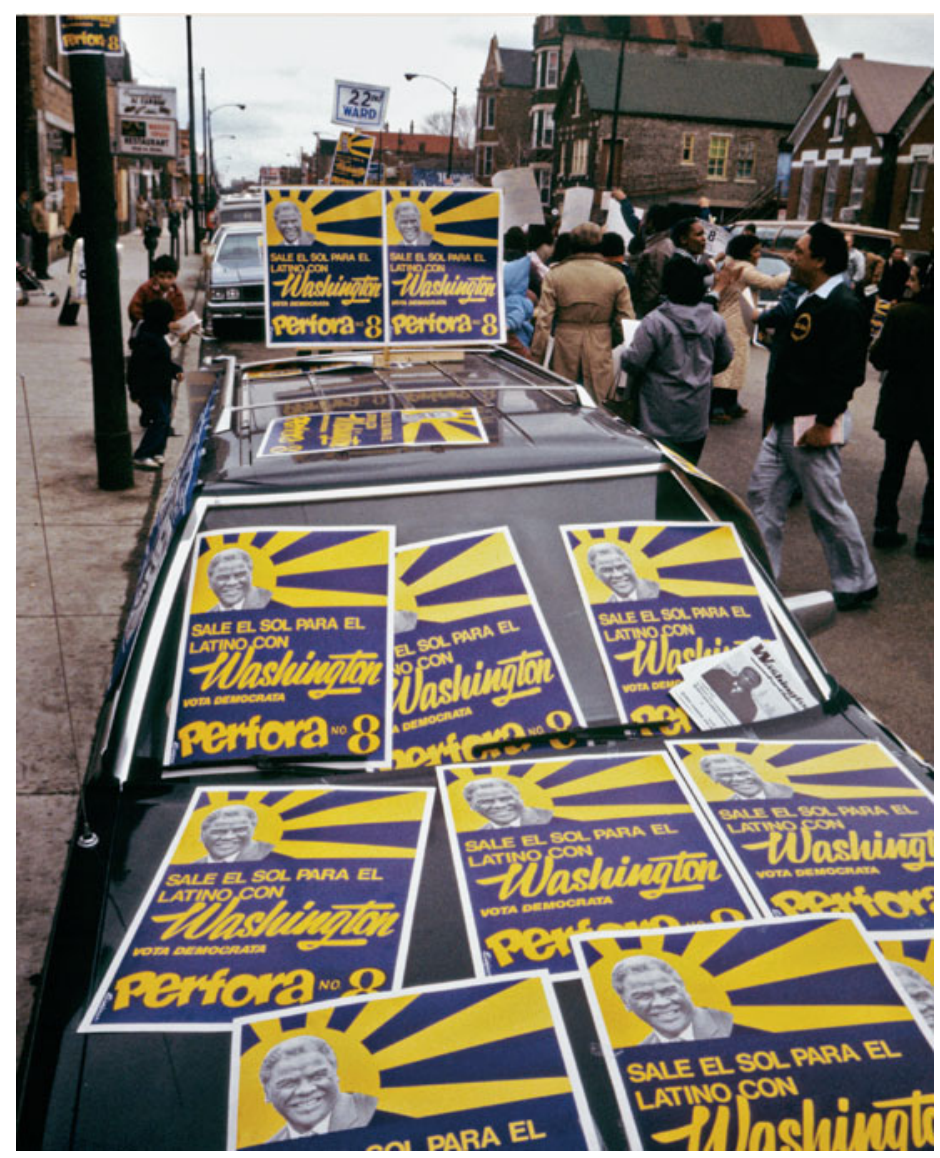

Figure 1. The Washington campaign's Sale El Sol slogan covered Latino neighborhoods leading up to the general election. "The Sun Rises for the Latino with Washington," the poster claimed, promising new opportunity and inclusion in City Hall for those diverse communities that the campaign unitarily labeled as the "Latino" constituency. Copyright (c) Marc PoKempner, "Image of Harold Washington campaign photos in Spanish on car," photograph, 1983, in Harold! Photographs from the Harold Washington Years (Evanston, IL, 2007), 116. Used with permission of Northwestern University Press.

panethnic labels "Latino" and "Hispanic." I add to this list political campaigns, like Washington's, that facilitated the discursive construction of a consolidated Latino constituency-joining the efforts of national entities such as the Congressional Hispanic Caucus. The Chicago story shows how a political campaign, the Latino political elites working within it, and corresponding media coverage contributed to the process of making Latinos a "legible" population in politics and beyond. ${ }^{9}$

\footnotetext{
${ }^{8}$ Felix M. Padilla, Latino Ethnic Consciousness: The Case of Mexican Americans and Puerto Ricans in Chicago (Notre Dame, IN, 1985); Arlene Dávila, Latinos, Inc.: The Marketing and Making of a People, 2nd ed. (Berkeley, CA, 2012); G. Cristina Mora, Making Hispanics: How Activists, Bureaucrats, and Media Constructed a New American (Chicago, 2014). See also Suzanne Oboler, Ethnic Labels, Latino Lives: Identity and the Politics of (Re)Presentation in the United States (Minneapolis, 1995); and Clara E. Rodríguez, Changing Race: Latinos, the Census, and the History of Ethnicity in the United States (New York, 2000).

${ }^{9}$ The concept of legibility comes from James Scott's theorization of the modern state, which "through its officials, attempts with varying success to create a terrain and a population with precisely those standardized characteristics that will be easiest to monitor, count, assess, and manage." James C. Scott, Seeing Like a State: How Certain Schemes to Improve the Human Condition Have Failed (New Haven, CT, 1998), 81-2.
} 
This project also helps bridge the divide between the literature on Black mayors and the political science research on Latino voters. A movement for Black political empowerment took hold of major urban hubs and led to Black mayoral victories starting in $1967 .{ }^{10}$ The early 1980s brought Latino mayors into the fold with the elections of Henry Cisneros in San Antonio and Federico Peña in Denver joining those of Harold Washington in Chicago and Wilson Goode in Philadelphia. But while the ascendancy of Black and Latino politicians was historically concurrent, studies on Black and Latino candidates do not generally intersect. In a context where studies on Black candidates emphasize the mobilization of Black voters, and studies on Latino candidates emphasize Latino mobilization, my approach to the election of Harold Washington uniquely highlights the reaction of Latino voters to a Black candidate. ${ }^{11}$ Thus when compared to Cisneros and Peña's near unanimous Mexican support, we can see how the "complexity of Latino racial identity" in Chicago, paired with negative reactions to Washington's Blackness, challenged the perceived inevitability of Latino voting blocs at the time. $^{12}$

Chicago's status as the largest majority-minority city in the nation elevated the 1983 election to a highly publicized test for Latinos' role in urban society. In the context of postwar deindustrialization, white flight, and segregation, recent works on Latino urbanism have established the unique vacancies filled by Latinos in commerce, art, culture, labor, racial hierarchies, geographic space, built environment, activism, and, in this case, formal electoral politics. My focus on the election reveals Latinos' indelible role in reshaping urban political regimes, or, as Llana Barber frames it, how Latinos "struggled not just within the city but for the city." ${ }^{3}$ Political activist

\footnotetext{
${ }^{10}$ For more on the rise of Black mayors, see John M. Allswang, "Tom Bradley of Los Angeles," Southern California Quarterly 74, no. 1 (Apr. 1992): 55-105; Roger Biles, "Black Mayors: A Historical Assessment," Journal of Negro History 77, no. 3 (Summer 1992): 109-25; David R. Colburn and Jeffrey S. Adler, eds., African-American Mayors: Race, Politics, and the American City (Urbana, IL, 2001); William E. Nelson, Jr., "Black Mayoral Leadership: A Twenty-Year Perspective," in Black Electoral Politics: Participation, Performance, Promise, ed. Lucius J. Barker (New Brunswick, NJ, 1990), 238-45; and J. Phillip Thompson, III, Double Trouble: Black Mayors, Black Communities, and the Call for a Deep Democracy (New York, 2006).

${ }^{11}$ Much like the aforementioned studies on Black mayors, works on Latino politics focus predominantly on the impact of co-ethnic candidates as a mobilizing force. For instance, see Matt A. Barreto, “iSi Se Puede! Latino Candidates and the Mobilization of Latino Voters," American Political Science Review 101, no. 3 (Aug. 2007): 425-41; Bernard L. Fraga, "Candidates or Districts? Reevaluating the Role of Race in Voter Turnout," American Journal of Political Science 60, no. 1 (Jan. 2016): 97-122; Corrine M. McConnaughy, Ismail K. White, David L. Leal, and Jason P. Casellas, "A Latino on the Ballot: Explaining Coethnic Voting Among Latinos and the Response of White Americans," Journal of Politics 72, no. 4 (Oct. 2010): 1199-211; and Gary M. Segura and Helena Alves Rodrigues, "Comparative Ethnic Politics in the United States: Beyond Black and White," Annual Review of Political Science, 9, no. 1 (2006): 375-95. Some notable exceptions to this trend examine the effect of a Black candidacy, and anti-Blackness, on Latino voters. For instance, see Andrea Benjamin, Racial Coalition Building in Local Elections: Elite Cues and Cross-Ethnic Voting (Cambridge, UK, 2017); Sarah Allen Gershon, Celeste Montoya, Christina Bejarano, and Nadia Brown, "Intersectional Linked Fate and Political Representation," Politics, Groups, and Identities 7, no. 3 (2019): 642-53; and Yanna Krupnikov and Spencer Piston, "The Political Consequences of Latino Prejudice Against Blacks," Public Opinion Quarterly 80, no. 2 (Summer 2016): 480-509.

${ }^{12}$ Cisneros was elected in 1981, followed by Peña, Washington, and Goode in 1983. Carlos Muñoz, Jr. and Charles Henry, "Rainbow Coalitions in Four Big Cities: San Antonio, Denver, Chicago, and Philadelphia," PS 19, no. 3 (Summer 1986): 598-609, here 607.

${ }^{13}$ Llana Barber, Latino City: Immigration and Urban Crisis in Lawrence, Massachusetts, 1945-2000 (Chapel Hill, NC, 2017), 9. For other notable works on historical Latino urbanism, see Mike Amezcua, "Beautiful Urbanism: Gender, Landscape, and Contestation in Latino Chicago's Age of Urban Renewal," Journal of American History 104, no. 1 (June 2017): 97-119; Genevieve Carpio, Collisions at the Crossroads: How Place and Mobility Make Race (Oakland, CA, 2019); Cary Cordova, The Heart of the Mission: Latino Art and Politics in San Francisco (Philadelphia, 2017); Perla M. Guerrero, Nuevo South: Latinas/os, Asians, and the Remaking of Place (Austin, TX, 2017); Jesse Hoffnung-Garskof, A Tale of Two Cities: Santo Domingo and New York after 1950 (Princeton, NJ, 2008); Johana Londoño, Abstract Barrios: The Crises of Latinx Visibility in Cities (Durham, NC, 2020); Sarah Lynn Lopez, The Remittance Landscape: Spaces of Migration in Rural Mexico and Urban USA (Chicago,
} 
Rudy Lozano was one such leader in the struggle for the city, whose life will serve as our guide through Latino Chicago's history of community organizing, the rise of independent politics, Washington's campaign, and finally the issue of historical memory in his death. As Latino Chicagoans struggled to define their political relationship to whiteness and to each other, Harold Washington's campaign for mayor prompted them to ask: “¿Qué somos? What are we?”"14

Like most Mexican American youth coming of age in Chicago during the 1960s, Rudy Lozano attended underfunded public schools and walked on neglected streets in a city divided by race. In the early 1970s, Lozano drew inspiration from his working-class upbringing as he found his calling in community organizing. One of his earliest experiences in the field came during college at the University of Illinois at Chicago, where he organized protests to increase student diversity and the number of Latino faculty. By 1979, Lozano had fully embraced organizing as his profession, evidenced in his role as the Midwest Organizing Director of the International Ladies Garment Workers Union (ILGWU), through which he made major gains in the unionization of underpaid Mexican American tortilla factory workers. ${ }^{15}$ By no means a path breaker in this regard, the young Lozano followed in the tradition of pan-Latino labor and community organizing in Chicago during the post-World War II era.

Causes such as school improvement and fighting urban renewal fueled the creation of civic groups such as Casa Aztlán, the Puerto Rican Cultural Center, El Centro de la Causa, and the Young Lords Organization. And while most groups catered to a specific national origin, Mexicans and Puerto Ricans began to unite around common causes starting in the late 1960s. Of all the pressing issues, however, fair access to employment opportunities became the predominant concern for Chicagoans of Latin American descent during the 1970s. Economic restructuring in that decade transitioned Chicago's workforce toward the service economy and white-collar jobs, but the majority of Latinos found themselves left behind in dying industries like manufacturing that "reinforced the role of Latinos in the Chicago economy as low-wage, dominated workers." ${ }^{16}$ A shared experience of discrimination and underemployment across Latino ethnic subgroups thus ushered in a new model of panethnic organizing spearheaded by the Spanish Coalition for Jobs (SCJ), identified by Felix Padilla as "Chicago's first Latino protest organization ... comprised of more than one Spanish-speaking group." ${ }^{7}$

Established in 1971, the Spanish Coalition for Jobs was a collective of twenty-three community organizations from both Mexican and Puerto Rican neighborhoods across the city that pushed for affirmative action in hiring. SCJ targeted the powerful Illinois Bell Telephone Company in its first major campaign, which, after months of picketing and tense negotiations, resulted in hundreds of jobs for Latino workers and new training initiatives. A year later, SCJ enjoyed similar success in its campaign against the Jewel Tea Company. ${ }^{18}$ Other panethnic labor coalitions,

2015), 201-48; and Andrew K. Sandoval-Strausz, Barrio America: How Latino Immigrants Saved the American City (New York, 2019).

${ }^{14}$ ¿Qué Somos? Nuestros Lazos Historicos Nos Unen, booklet, Mar. 1983, folder 5, box 25, Harold Washington Mayoral Campaign Records, Special Collections, Chicago Public Library, Chicago, IL [hereafter HWMCR].

${ }^{15}$ ILGWU had a long history of organizing Latina women in California, Texas, and New York. For instance, see Lori A. Flores, "An Unladylike Strike Fashionably Clothed: Mexicana and Anglo Women Garment Workers Against Tex-Son, 1959-1963,” Pacific Historical Review 78, no. 3 (Aug. 2009): 367-402; and Altagracia Ortiz, "Puerto Rican Workers in the Garment Industry of New York City, 1920-1960," in Labor Divided: Race and Ethnicity in United States Labor Struggles, 1835-1960, eds. Robert Asher and Charles Stephenson (Albany, NY, 1990), 105-25.

${ }^{16}$ John J. Betancur, Teresa Cordova, and Maria de los Angeles Torres, "Economic Restructuring and the Process of Incorporation of Latinos into the Chicago Economy," in Latinos in a Changing U.S. Economy: Comparative Perspectives on Growing Inequality, eds. Rebecca Morales and Frank Bonilla (Newbury Park, CA, 1993), 109-32, here 127.

${ }^{17}$ Padilla, Latino Ethnic Consciousness, 90.

${ }^{18}$ Ibid, 92-102. 
such as Asociación pro Derechos Obreros (Association for Workers' Rights) and the Latin American Task Force, soon followed the momentum set by SCJ and pushed for affirmative action not only in the private sector, but also in public entities such as the Chicago Transit Authority and other city employers. ${ }^{19}$ Despite these gains, low union membership and the dispensability of undocumented workers prompted these groups to realize that tangible gains for Latino workers also called for a wholesale transformation of the city's political order. ${ }^{20}$

Latino labor activism helped set the stage for the independent political movement of the 1980s that fixed its eyes on dismantling the Machine's patronage system. The City of Chicago employed tens of thousands of people, but "jobs and economic favors were differentially and disproportionately allocated, based upon voting strength." ${ }^{21}$ In addition to thousands of patronage jobs or "temporary appointments" at the disposal of the mayor, the Machine also held sway over trade unions and the private sector through government contracts, licensing, and setting the prevailing wage in select industries. ${ }^{22}$ Though some groups such as the Mexican American Democratic Organization (MADO) sought to bring Machine spoils to their communities, decades of continued economic stagnation proved to many that collaboration with Mayor Richard J. Daley and his successors only produced symbolic gestures and a handful of token appointments. ${ }^{23}$ In this context, some community activists, including Rudy Lozano, shifted their efforts from strikes and protests to the political realm in order to advance the material wellbeing of the Latino community.

Lozano co-founded the Independent Political Organization (IPO) of the Twenty-Second Ward in 1981, one of many IPOs across Chicago part of a broader independent political movement in Black and Latino wards. Though these organizations worked almost exclusively at the local level on ward-specific campaigns, the independent movement found its first major BlackLatino partnership in the contest for the 1982 Illinois legislature. Officially launched in January of that year, the "Black-Latino Alliance" assembled a multiracial slate of "people-oriented candidates" composed of Danny Davis, Jane Flagg, Arthur McBridge, Jose Salgado, Juan Solíz, Arthur Turner, and Carmelo Vargas-all of whom ran against Machine-backed incumbents. ${ }^{24}$ Major Spanish-language newspaper El Heraldo de Chicago noted the significance of this challenge to the city's political machine that had "traditionally given its support to other ethnic groups at the expense of blacks and Latinos." ${ }^{25}$ But what some observers considered "an important test of political strength for Latinos in Chicago" ended with Machine victories and no new Latino representation in the statehouse. ${ }^{26}$

\footnotetext{
${ }^{19}$ Fernández, Brown in the Windy City, 210, 234.

${ }^{20}$ Latinos only made up about 5-7 percent of all Chicago union members, an incredibly low proportion considering that Latinos were overrepresented among manual laborers. See Milton Derber, Labor in Illinois: The Affluent Years, 1945-80 (Urbana, IL, 1989), 404.

${ }^{21}$ Abdul Alkalimat and Doug Gills, "Black Power vs. Racism: Harold Washington Becomes Mayor," in The New Black Vote: Politics and Power in Four American Cities, ed. Rod Bush (San Francisco, CA, 1984), 53-179, here 66; Dick W. Simpson, Rogues, Rebels, and Rubber Stamps: The Politics of the Chicago City Council from 1863 to the Present (Boulder, CO, 2001).

${ }^{22}$ It is estimated that some 30,000 patronage jobs were at the disposal of the mayor during the peak of the Daley regime. By 1980, many jobs were redirected into the career service with 25,000 civil servants and a remainder of 14,900 patronage slots. Derber, Labor in Illinois, 235-6; Anne Freedman, "Doing Battle with the Patronage Army: Politics, Courts, and Personnel Administration in Chicago," Public Administration Review 48, no. 5 (Sept.-Oct. 1988): 847-59, here 848 .

${ }^{23}$ For more on MADO and Latino-Machine relations, see Amezcua, "A Machine in the Barrio," 98-102.

${ }^{24}$ Slim Coleman, "Black-Latino Alliance Formed," All Chicago City News, Feb. 18, 1982, 2, 10, folder 48, box 4, Rudy Lozano Papers, Special Collections and University Archives, University of Illinois at Chicago, Chicago, IL [hereafter RLP].

${ }^{25}$ Author's translation of "El cual tradicionalmente ha dado su apoyo a otros grupos étnicos a expensas de los negros y los latinos." Alicia C. Santelices, "Latinos Y Negros: Contra La Maquinaria Democrata," El Heraldo de Chicago, Feb. 4, 1982, folder 48, box 4, RLP.

${ }^{26}$ Bill Campillo, "Soliz Challenges 'The Machine," La Opinion Latina, Winter 1982, folder 2, box 1, RLP.
} 
Regardless of the Black-Latino Alliance's disappointing electoral returns, their candidacies created strong momentum for the independent movement leading up to the 1983 city elections. In late 1982, Rudy Lozano officially threw his hat in the ring and entered the world of electoral politics as a candidate for alderman of the Twenty-Second Ward, one of fifty city council districts. The Twenty-Second Ward was home to the Mexican enclave of Little Village and boasted the highest density of Latino residents in the entire city at 64 percent, as well as a substantial Black population at 21 percent. ${ }^{27}$ Despite its majority-minority composition, a white politician named Frank Stemberk represented the ward in City Hall and was fiercely loyal to the Regular Democratic Organization. Mexican American residents considered the alderman completely out of touch with their community and came to know him as the "absentee alderman," a title that proved to be quite literal when he was eventually investigated by the Cook County State's Attorney for living in the suburbs rather than within city limits (let alone the ward he represented). ${ }^{28}$

Lozano's campaign reflected the growing desire for self-governance among Latino Chicagoans and was closely aligned with the independent movement's mayoral contender, U.S. Representative Harold Washington. Washington was a reform candidate poised to become the city's first African American mayor. Originally, Washington hesitated to run again in 1983 due to a previously failed attempt and concerns over historically low Black voter turnout. An unprecedented surge in Black voter registration numbering in the tens of thousands, mobilized by Washington's barrier-breaking candidacy, however, rapidly assuaged his reservations. ${ }^{29}$ With the full backing of the Black electorate, Washington pushed forward with an independent agenda that challenged the Machine's patronage system and promoted the equitable distribution of city jobs and services. Seeking to bring together a "rainbow coalition," as well as unleashing the full potential of the independent political movement, Washington also extended the reach of his campaign through a series of partnerships that included endorsing Lozano's bid for alderman.

Washington faced two other candidates, Jane Byrne and Richard M. Daley, in the 1983 Democratic primary for mayor. Byrne, the first woman elected mayor of Chicago in 1979, was well supported in white working-class neighborhoods and benefited from her status as the incumbent. She struggled, however, in her relationship to impoverished African Americans living in the South Side who criticized her failure to address job decline and dilapidated public housing. By the eve of the election, she consistently found herself in hot water with Black and Latino activists on many issues including labor disputes, public housing, a failing school system, and the lack of non-white political appointees. ${ }^{30}$ Cook County State's Attorney Richard M. Daley posed the most significant challenge to Byrne's re-election campaign among ethnic white voters, benefitting from his legacy as son of former Mayor Richard J. Daley who held office for twenty-one years. Together, Byrne and Daley confidently courted the majority of white voters in Chicago, most of whom were deeply invested in the maintenance of patronage that benefitted their neighborhoods.

Whereas white neighborhoods split between Byrne and Daley, and Black voters unanimously supported Washington, the allegiance of Latino voters was subject to wide-ranging speculation. Mainstream media outlets such as the Chicago Tribune pointed to a lack of

\footnotetext{
${ }^{27}$ Juan Andrade and Connie Ortega, Hispanics in Chicago: A Political Analysis (Chicago, 1982).

${ }^{28}$ María de los Ángeles Torres, "In Search of Meaningful Voice and Place: The IPO and Latino Community Empowerment in Chicago," in La Causa: Civil Rights, Social Justice and the Struggle for Equality in the Midwest, ed. Gilberto Cárdenas (Houston, TX, 2004), 81-106, here 91; Robert Davis and James Strong, "Alderman's Residency Investigated," Chicago Tribune, May 10, 1985, A1.

29"Voter Registration Catches On," Chicago Tribune, Dec. 15, 1982, 18; Travis, "Harold," The People's Mayor, 140.

${ }^{30}$ Alkalimat and Gills, "Black Power vs. Racism," 70-1, 82; Derber, Labor in Illinois, 406; Sandoval-Strausz, Barrio America, 206-8.
} 
centralized leadership as the source of Latino political disunity. The Tribune's 1982 cover story asked, "Who Speaks for Hispanic Americans?" Journalist Manuel Galvan described Chicago as "the one heavily Hispanic city that mirrors the special problem of Hispanics nationally-it does not have a Hispanic spokesman for its entire population. Instead, the various communities have their movers and shakers, who sometimes work together and sometimes fight." 31 Indeed, Chicago's Mexicans, Puerto Ricans, and Cubans had their own respective community leaders who rarely joined forces and complicated the creation of an intra-ethnic political bloc-a microcosm of the challenges facing the unity of the national Latino electorate at the time.

But in an election so focused on jobs and city resources, the 1983 mayoral primary revealed the centrality of anti-Black thinking in Latino political decision making, an issue that hampered Latino political unity far more than decentralized leadership. Harold Washington's candidacy exacerbated Latinos' existing anxieties from earlier decades regarding unemployment and the unequal distribution of city services, though this time they feared that a Black mayor would make matters worse by favoring African Americans over Latinos in the allocation of resources and jobs. The Daley campaign embraced this anti-Black rhetoric early on to deter Latino support for Washington. Daley accepted the endorsement of a 250-member coalition of six Latino organizations in December 1982. The group's spokesperson, Lupe Perez, warned of the pro-Black favoritism that Washington would practice in office and labeled him "a civil rights candidate of the black community and not a political candidate to represent all the citizens of Chicago." 32 Though the coalition also denounced Byrne for neglecting Latino community development, their critique of Washington was explicitly racial.

Mayor Jane Byrne also adopted the rhetoric of racial resource competition in her re-election campaign. A televised debate on February 7, 1983, on WBBS-TV's Spanish-language public affairs program Opinion Publica, put Byrne's strategy on full display. Latino representatives from the three Democratic mayoral campaigns addressed a variety of topics on behalf of their candidates, and affirmative action in city hiring raised the most controversy. Byrne's assistant press secretary for Spanish communication, Colombian-born Fernando Prieto, spoke on her behalf and emphasized the zero-sum game for Latinos under a Washington administration. "We can go to the Department of Human Services and we will see how that department is very dark," Prieto said of the department's many Black employees, "can you imagine how it would be with a Black mayor?" Though some community leaders such as Puerto Rican minister Jorge Morales demanded an apology from Byrne for the "use of these racist tactics" that sought to pit Latinos against Blacks, Prieto's statement likely validated the fears of many Latinos hoping to earn a city job. ${ }^{33}$

Though Congressman Harold Washington was aware of his opponents' strategy to exaggerate the economic competition between Blacks and Latinos, he underestimated its influence on Latino voters during the primary. Washington operated under the assumption that Latinos already viewed themselves in racial terms on par with Blacks, and thus expected that his message of racial uplift for Black voters would naturally carry over to Latinos. This erroneous assumption was the Achilles heel in his failed run for mayor in the 1977 special election. Steve Askin, press secretary for the 1977 Washington mayoral campaign, outlined for Washington the lack of Latino support for his candidacy in a postmortem campaign analysis and warned, "it is often blithely assumed that Spanish-speaking voters will align themselves with blacks." ${ }^{34}$ Unfortunately, Washington's primary campaign failed to heed that lesson six

\footnotetext{
${ }^{31}$ Manuel Galvan, "Who Speaks for Hispanic Americans?" Chicago Tribune, June 20, 1982, A1. See also "City Latinos Have Almost No Political Power: Study," Chicago Tribune, Feb. 21, 1980, W2.

32"Latino Coalition Endorses Daley," Chicago Tribune, Dec. 6, 1982, 15.

${ }^{33}$ Marcelino Miyares Sotolongo, President of WBBS-TV, to Washington campaign, Jan. 13, 1983, folder 10, box 26, HWMCR; Jorge Morales, press release statement, Feb. 17, 1983, folder 12, box 26, HWMCR.

${ }^{34}$ Steve Askin, “After the 1977 Election: A Strategic Assessment and Some Thoughts for the Future," Apr. 29, 1977, folder 53, box 1, Steve Askin Papers, Special Collections, Chicago Public Library, Chicago, IL, 2.
} 
years later, with an outreach to Latino voters incomparable to the massive grassroots mobilization that characterized his ground game in the Black South Side.

The perception that Washington collapsed the Latino experience into the Black agenda worsened his appeal. The viewpoint of Mexican American data-entry operator Marie Helen de la Cruz clearly illustrates the candidate's struggle to relate, as seen in her negative reaction to Washington saying that Latinos were also "niggers" - an attempt to equate Latino and Black oppression. Washington's comparison was not new to U.S. politics, reflecting a similar statement by Congressman Ronald V. Dellums: "If you're black, you're a nigger. If you're an amputee, you're a nigger. Blind people, women, students, the handicapped ... are all niggers." ${ }^{35}$ Yet for voters like de la Cruz, that kind of rhetoric was both polarizing and offensive, suggesting that Washington viewed politics only in Black terms and would merely use Latinos to achieve his own community's goals. "It would be wrong for people to assume that Latinos will support Washington because he is black," said de la Cruz, “... I don't see why there should be a natural coalition between blacks and Latinos." ${ }^{36}$

Of Washington's few Latino outreach events during the primary, only Tony Bonilla's visit to Chicago directly addressed Latinos' concerns about electing a Black mayor. ${ }^{37}$ Bonilla was president of the League of United Latin American Citizens (LULAC), the oldest national Latino civil rights organization, established in 1929. Jesse Jackson's urban justice group, Operation PUSH, flew Bonilla in from Texas to a rally where the LULAC leader endorsed Washington's bid for mayor just weeks before the primary (Figure 2). Bonilla framed his endorsement as a challenge to anti-Black thinking in the Latino community and told the racially diverse crowd that he had received numerous calls asking why he was "working with the enemy-Blacks." In response to this zero-sum game mindset, Bonilla asserted that "it is time for Blacks and Hispanics to stop fighting," calling for unity between "tacos and biscuits." 38 But this ringing endorsement from a national Latino figurehead did not boost local Latino support.

On February 22, 1983, Harold Washington won the Chicago Democratic primary with 36.3 percent of the vote; Byrne arrived in second place with 33.6 percent, and Daley in third at 29.7 percent. ${ }^{39}$ Washington won a narrow victory margin because of an unprecedented Black voter turnout and a white electorate split between Byrne and Daley. But when it came to Latino voters, Washington's performance was abysmal. The Midwest Voter Registration Education Project's primary election exit poll found that 51.4 percent of Latinos supported Byrne, 34.5 percent for Daley, and only 12.7 percent voted for Washington. ${ }^{40}$ Washington failed to win any of the heavily Latino wards, such as the Seventh Ward in which Byrne and Daley carried the Mexican vote. Similarly in the Thirty-Second Ward, approximately half Latino, Byrne carried the Latino precincts and Daley the white neighborhoods. ${ }^{41}$ The fact that unpopular incumbent Byrne received the majority of Latino votes-despite major political blunders on her part,

\footnotetext{
${ }^{35}$ Martin Tolchin, "For Blacks, Racism and Progress Mix," New York Times, Mar. 11, 1983, A20.

${ }^{36}$ Patner, "A Time to Listen."

${ }^{37}$ Washington's Latino outreach in the primary was characterized by a few social events such as the "Blues and Salsa" benefit concert and others like it. "Blues and Salsa Benefit Party," Jan. 29, 1983, and "Benefit Concert Invitation," Feb. 19, 1983, folder 16, box 11, HWMCR.

${ }^{38}$ Chinta Strausberg, "Urges Minority Coalition: Hispanic Leader Vows Interracial Unity," Chicago Defender, Jan. 31, 1983, folder 28, box 36, HWMCR.

39“1983 Chicago Mayoral Primary Election Results," Chicago Democracy Project, http://chicagodemocracy.org/ ElectionResults.jsp?election=crdd_primary,crdd_1983_primary_election,il_chi_mayor_dem (accessed Aug. 13, 2021).

${ }^{40}$ María de los Angeles Torres, "The Commission on Latino Affairs: A Case Study of Community Empowerment," in Harold Washington and the Neighborhoods: Progressive City Government in Chicago, 19831987, eds. Pierre Clavel and Wim Wiewel (New Brunswick, NJ, 1991), 165-87, here 171.

${ }^{41}$ David K. Fremon, Chicago Politics, Ward by Ward (Bloomington, IN, 1988), 61, 215.
} 


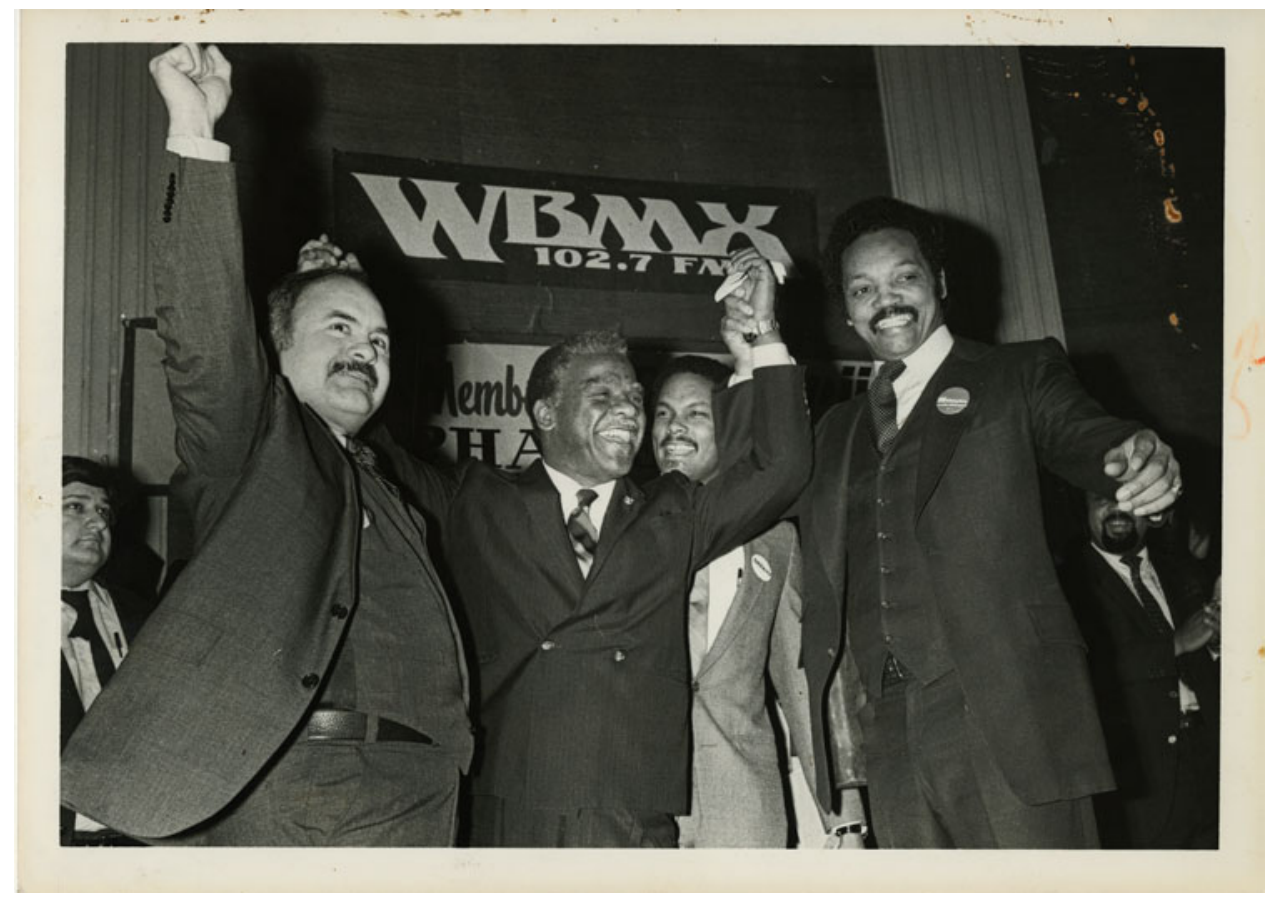

Figure 2. Tony Bonilla, Congressman Harold Washington, and Jesse Jackson at a rally convened by Jackson's organization Operation PUSH in January 1983. David Williams, photograph, Jan. 1983, folder 26, box 3, Pre-Mayoral Photograph Collection, Harold Washington Archives and Collections, Special Collections, Chicago Public Library, Chicago, IL. Used with permission of Chicago Defender.

including the removal of nearly all Latino appointees from the previous administration without replacement-spoke volumes to Latino distrust of the Black candidate. ${ }^{42}$

Latinos' historically varied racial formations and spatial positioning in relation to Blacks helps contextualize the salience of anti-Blackness among Latinos in the 1983 election. Over 420,000 Latinos called Chicago home in the 1980s, accounting for 14 percent of the city's population. Chicago also boasted the only substantial urban representation of the nation's three largest Latino subgroups-Mexican, Puerto Rican, and Cuban-an unparalleled demographic spread that laid bare the differences between Latino subgroups, especially in their relationship to whiteness (Table 1). How Latinos categorized themselves along the city's Black/white racial binary deeply shaped political proclivities to either join the Machine's ethnic white base or ascribe to a rights-based, minority identity. Defining one's racial identity, however, had proven a challenging and divisive exercise for all subgroups. One Latino Chicagoan summed it up for the Chicago Tribune in a 1974 man-on-the-street interview: "Blacks call us white, whites call us brown, and we have a helluva time deciding what we're going to call ourselves!" 43

Mexicans were the first Latinos to arrive in Chicago, with the pioneer wave settling in South Chicago during the 1910s. Historians such as Michael Innis-Jiménez have shown how this group developed a distinctly racialized Mexican identity, a product of discrimination in labor and society as well as their "selective resistance" to cultural assimilation. Nevertheless, Mexicans also benefitted from their distance to Blacks in employment and housing, occupying

\footnotetext{
${ }^{42}$ Phillip Lentz, "Hispanics Hunger for Clout in City Hall," Chicago Tribune, Jan. 31, 1983, A1; Derber, Labor in Illinois, 406.

${ }^{43}$ Mike LaVelle, "Latino Efforts to Pull Together," Chicago Tribune, Aug. 1, 1974, 16.
} 
Table 1. Latino population in Chicago by national origin, 1980

\begin{tabular}{lll}
\hline Origin & Population & Percent of all Latinos \\
\hline Mexican & 255,802 & $60.61 \%$ \\
\hline Puerto Rican & 112,074 & $26.55 \%$ \\
\hline Cuban & 11,513 & $2.73 \%$ \\
\hline Other & 42,674 & $10.11 \%$ \\
\hline Total & $\mathbf{4 2 2 , 0 6 3}$ & $100 \%$ \\
\hline
\end{tabular}

Source: U.S. Department of Commerce, Bureau of the Census, "Table 70: Total Persons and Spanish Origin Persons by Type of Spanish Origin, Race, and Sex, for Areas and Places: 1980," in 1980 Census of Population, vol. 1, ch. B, pt. 1, (Washington, DC, 1983), 278.

a liminal third space in Chicago's Black/white binary. ${ }^{44}$ By the 1970 s, the growth of both the Mexican and Black populations resulted in greater encounters and less geographic distance between the two groups, especially in the Near West Side. One study characterized Mexicans' reaction to the shrinking spatial boundaries between them and Blacks as "dissatisfaction with 'bad elements' becoming more numerous" in their neighborhoods. ${ }^{45}$ The rise of Chicano nationalism further complicated Mexican Chicago's identity. While a new activist generation wholly rejected whiteness and assimilation, an equal proportion of Mexicans continued to define themselves in contrast to Blackness by making "highly contested and locally dependent" claims to whiteness. ${ }^{46}$

Puerto Ricans, Chicago's second-largest Latino ethnic group, settled on the Near North Side in neighborhoods such as Lincoln Park and Lakeview after decades of displacement due to urban renewal. They originally came to Chicago by way of higher education and state-sponsored labor migration as early as the $1940 \mathrm{~s} .{ }^{47}$ Like other Latino groups, Puerto Ricans inherited a legacy of colorism from Spanish conquest that actively repressed their African ancestry. But their unique status as U.S. colonial subjects and the racialization of darkskinned Puerto Ricans as Black allowed for greater acceptance of a racial minority identity over an ethnic one. "Despite the hostilities that existed between Puerto Ricans and black Americans," argues Young Lords scholar Johanna Fernández, "their common experiences with racism opened up the possibility of shared identification." Moments like the Division Street Riots of 1966, incited by the killing of a young Puerto Rican man by the Chicago Police Department, increased the racial proximity between Puerto Ricans and African Americans in Chicago compared to other Latinos. ${ }^{48}$

Cubans were the third-largest group and lived mostly in Chicago's Far North Side, a location that created "the least amount of Black association" of all Latino groups. ${ }^{49}$ Their distance from Black neighborhoods was intentional given that many Cubans arrived with professional backgrounds and actively aspired to ascend the class ladder, similar to white ethnics, and requiring a

\footnotetext{
${ }^{44}$ Michael Innis-Jiménez, Steel Barrio: The Great Mexican Migration to South Chicago, 1915-1940 (New York, 2013), 9, 34. See also Gabriela F. Arredondo, Mexican Chicago: Race, Identity, and Nation, 1916-39 (Urbana, IL, 2008); and Deborah E. Kanter, Chicago Católico: Making Catholic Parishes Mexican (Urbana, IL, 2020).

${ }^{45}$ Gerald William Ropka, The Evolving Residential Pattern of the Mexican, Puerto Rican and Cuban Population in the City of Chicago (New York, 1980), 169.

${ }^{46}$ Fernández, Brown in the Windy City, 221.

${ }^{47}$ Mérida M. Rúa, A Grounded Identidad: Making New Lives in Chicago's Puerto Rican Neighborhoods (New York, 2012).

${ }^{48}$ Johanna Fernández, The Young Lords: A Radical History (Chapel Hill, NC, 2020), 24; Fernández, Brown in the Windy City, 133-47.

${ }^{49}$ Ropka, The Evolving Residential Pattern of the Mexican, Puerto Rican and Cuban Population in the City of Chicago, 168.
} 
racial-spatial separation from Blacks. Like their compatriots in Miami, Cuban Americans in Chicago also espoused a conservative exile politics that favored Republican President Ronald Reagan's "get tough with Cuba" policy. ${ }^{50}$ But unlike Miami, Chicago's most conservative and socioeconomically mobile Cubans quickly moved to the suburbs, a process of self-selection that resulted in a conservative majority paired with a large contingent of second-generation Cubans who were more progressive. Intra-ethnic encounters also shifted Cuban politics in Chicago. In author Achy Obejas's experience, she found that her community was in "constant contact with other Latinos ... so we are constantly challenged in our thinking in ways that we wouldn't be in Miami." 51

While these complex histories certainly influenced Latino preferences in the primary, the issue of anti-Blackness came to the fore in an unprecedented general election challenge. Winning the Democratic primary in Chicago had traditionally been tantamount to winning the general election. But for many in the political establishment, Washington's reform platform threatened to be the death knell for the city's patronage system. So, for the first time, Democratic leaders rejected their party's nominee by endorsing Republican Bernard Epton for mayor in an otherwise one-party city. And so went the majority of ethnic white voters that followed their aldermen to the Republican side, if just for one election. Epton, a lawyer and state legislator, exacerbated the racial divide of the primary. Notably, his campaign slogan "Before It's Too Late" warned of a Black takeover of city hall. ${ }^{52}$ As one journalist observed of Epton's ads, "Political messages here are being delivered in code ... after all, it would be impolite, maybe even impolitic, to come right out and say: "Now-before the blacks take over." 53

While Epton established the decidedly racial tone of the general election, Harold Washington confronted the fact that he had failed to build a true rainbow coalition. Washington won the primary thanks only to unanimous backing from the Black electorate, meaning that his mayoral aspirations now depended on a more deliberate Latino outreach strategy. The devastating realization that 87.3 percent of Latinos voted against Washington caused his campaign to revamp its approach and enlist the help of Latino staffers in the forty-nine days leading up to the April general election. Similarly, Rudy Lozano also found himself in an unexpected position, having lost in the primary election against the entrenched incumbent alderman, whose financial and organizational support from the Machine outmatched the young activist. Nevertheless, Lozano quickly transitioned to Washington's campaign full time and became his "main liaison to the Latino community." 54 Now a campaign staffer, Lozano sought to unify the city's Latino electorate behind Washington.

Even though the Washington campaign desperately needed a concerted Latino outreach program, it still took over two weeks after the primary to adopt an official Latino campaign branch. Pressure from community and labor activists like Linda Coronado, also working for Washington, accelerated the establishment of the campaign's Latino Operations Department. Far beyond the task of bringing former Byrne and Daley supporters into the fold, the Latino Operations Department intentionally appealed to a singular pan-Latino constituency. For

\footnotetext{
${ }^{50}$ Torres, In the Land of Mirrors, 121.

${ }^{51}$ Qtd. in Wilfredo Cruz, City of Dreams: Latino Immigration to Chicago (Lanham, MD, 2007), 173.

${ }^{52}$ The prospect of a Black mayor spurred language of a "Black takeover" in a variety of mayoral races involving a Black candidate, such as those in Newark, Atlanta, and New Orleans. For instance, see Richard Connolly, "Tense Newark Chooses a Mayor Today: 'Corruption' vs. 'Black Takeover' the Themes as New Jersey Campaign Ends," Boston Globe, June 16, 1970, 2; Phil Garner, "The Race for Mayor: Fruit Basket Turnover," Atlanta Constitution, Sept. 30, 1973, SM1; and B. Drummond Ayres, Jr., "First Black Mayor of New Orleans, at Inauguration, Promises a New Era," New York Times, May 2, 1978, 18. For more on dog whistle appeals, see Ian Haney López, Dog Whistle Politics: How Coded Racial Appeals Have Reinvented Racism and Wrecked the Middle Class (Oxford, UK, 2014).

${ }^{53}$ Richard Reeves, "Chicago Vote Tests Black and White Rules," Green Bay Press Gazette, Mar. 26, 1983, 14. This article was printed in newspapers across the country due to Reeves's syndication with the Universal Press Syndicate.

${ }^{54}$ Gary Rivlin, “Who Killed Rudy Lozano?” stapled booklet, c.1983, folder 37, box 4, RLP.
} 
activists like Lozano and Coronado, who had been at the forefront of panethnic organizing during the previous decade, their involvement in the Washington campaign offered a unique opportunity to make manifest their vision of a shared Latino identity among Mexicans, Puerto Ricans, and others. Thus, what news outlets framed as the Latino toss-up vote during the general election, the Washington campaign endeavored to transform into a cohesive Latino voting bloc. ${ }^{55}$

More importantly, the Latino Operations Department sought to shepherd Latino voters through the citywide shift from ethnic politics to racial politics. Given Latinos' liminal position in Chicago's racial hierarchy, the 1983 election forced them to decide whether their interests and values aligned more with Black or white voters. As such, the Washington campaign needed to convince Latinos that they would be best served by voting as a non-white minority bloc due to their racialized status in society and shared economic disadvantage with Blacks. With this task in mind, the department focused its efforts on the production of Spanish-language campaign materials, pushing panethnic messages in the media, and hosting Latino unity events. ${ }^{56}$ These three priorities allowed the campaign to raise important issues concerning Latino ethnoracial identity and political consciousness through various outlets. All of these efforts addressed the pressing need to inoculate Latinos against the anti-Black rhetoric that influenced their vote in the primary and continued to hold sway in the general.

The Latino Literature Review Committee (LLRC) focused on the creation, publication, and distribution of campaign literature that targeted Latino voters, all printed in Spanish or bilingually. Evidence of the Washington campaign's panethnic mission can be drawn from even the most mundane process of designing a campaign button. At first, two designs were considered: 50,000 buttons with a Puerto Rican theme and 50,000 with a Mexican American theme. But a majority of committee members resisted this idea and instead "suggested consideration be given to one button with [a] design that covers Puerto Rican, Mexican, et al." ${ }^{\prime 7}$ This was also a practical consideration for the campaign. Rather than address each Latino subgroup separately, a panethnic appeal similar to that employed in presidential elections was more economical. The popular slogan "Sale el Sol para el Latino con Washington" [The Sun Rises for the Latino with Washington] ultimately took form as buttons and posters that graced jackets and lampposts across the city.

A flyer entitled “¿Qué Somos..?” [What Are We..?] captured the campaign's effort to foster a new kind of racial-political consciousness. "What Are We?" was brought up as a major campaign theme at the LLRC's very first meeting on March 9, and though participants suggested nationality-specific flyers, this particular message won out due to its "broad Latino appeal." 58 “¿Qué Somos..?” was a beginner’s guide to Latino identity that walked readers through the complexity of racial self-identification (Figure 3). "We know for sure that we are not Europeans, nor Indian/Indigenous nor Africans," the flyer posited, "then, who are we?"59 It explained that Latinos are descended from those three races, birthed from a shared history of racial mixing and colonization. It stressed the importance of unity between different groups of Latinos as a single racial minority group, despite differences in nationality and phenotype. This panethnic appeal was clearly visualized on the cover, which featured a multiracial group of Latinos and another image consisting of a united cluster of people holding up different Latin American flags.

\footnotetext{
${ }^{55}$ David Axelrod, "Washington's New Focus," Chicago Tribune, Feb. 27, 1983, A1; Basil Talbott, "Two Key Mayor Battlegrounds," Chicago Sun-Times, Mar. 13, 1983, A1.

${ }^{56}$ Peter Earle and Linda Coronado to Campaign Manager Al Raby, memorandum, Mar. 1, 1983, folder 11, box 4, HWMCR.

${ }^{57}$ Latino Literature Committee minutes, Mar. 9, 1983, folder 9, box 5, HWMCR.

${ }^{58}$ Summary of Latino Literature Review Committee Meeting, Mar. 9, 1983, folder 11, box 4, HWMCR.

59“¿Qué Somos? Nuestros Lazos Historicos Nos Unen,” flyer, Mar. 1983, folder 5, box 25, HWMCR, 2.
} 

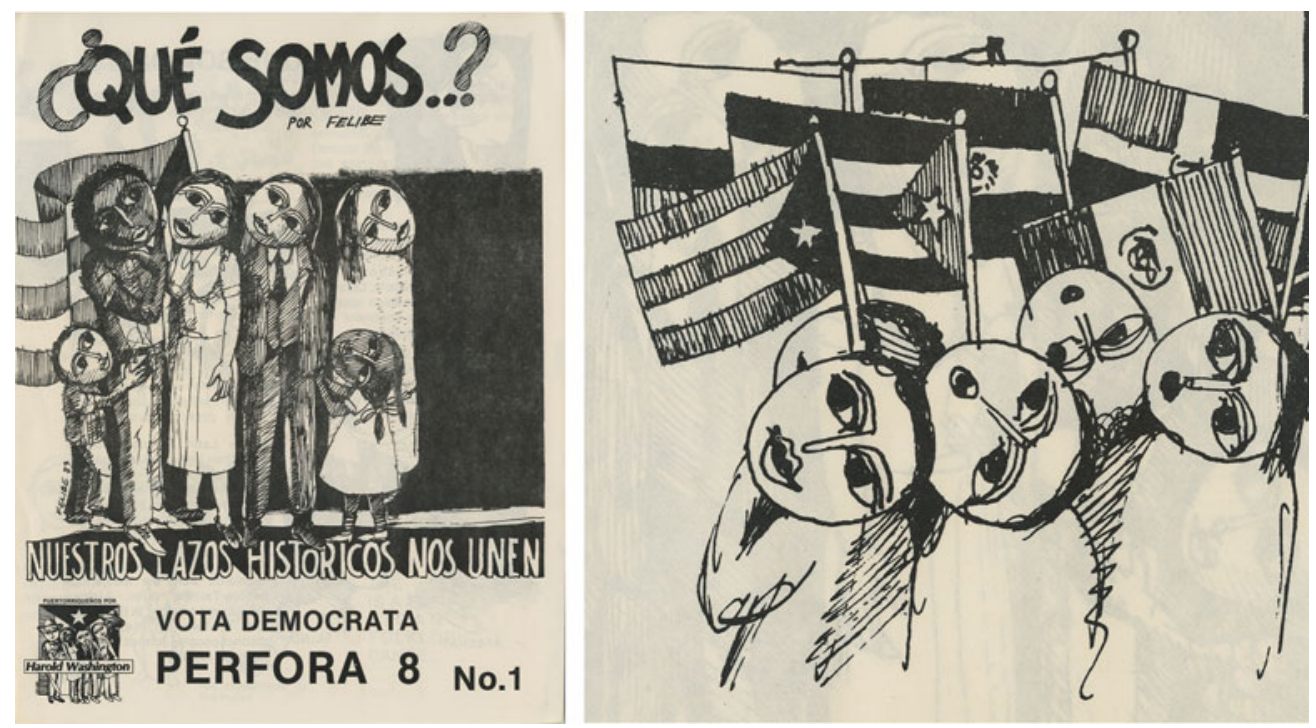

Figure 3. Cover of Qué Somos? and cropped image of interior. From Qué Somos..? Mar. 1983, folder 5, box 25, HWMCR. Courtesy of Chicago Public Library.

“¿Qué Somos..?” also demonstrated the LLRC’s commitment that all Latino campaign literature be "in line with Harold Washington's policy in developing the Black/Brown ties." ${ }^{\prime 20}$ The flyer ended its lesson on Latino identity by arguing that "Latinos face the same economic and social prejudice as black people. We must come together." ${ }^{61}$ This call for unity was a clear response to concerns expressed in progressive Latino circles regarding the influence of anti-Blackness in the primary, which risked hampering interracial unity if left unaddressed. The March newsletter from Puerto Rican education nonprofit ASPIRA discussed the need for a Black-Latino coalition after Washington's primary victory. Given the lack of Latino support for Washington during the primary, the organization saw the general election as a critical moment during which "the Latino population in Chicago must put aside their anti-black attitude." ${ }^{62}$ In this way, the campaign's targeted publications implied linked fate between Latinos and Blacks across the city, offering an alternate narrative to the public discussion about resource competition between racial groups. ${ }^{63}$

The Washington campaign also engaged in a large-scale media effort that complemented the general literature distributed in Latino neighborhoods. Several Spanish-language and bilingual radio spots for Washington flooded the airwaves during the last week of the campaign in early April. Washington's Media and Advertising Coordinator Bill Zayas hired Rossi Advertising to target a panethnic Latino audience in both print and broadcast media. The firm's owner, Uruguayan Luis H. Rossi, was an early architect of Chicago's Latino media and panethnic consumer market who popularized promotional "Hispanic days" at major entertainment events and published the prominent newspaper La Raza. ${ }^{64}$ It is no surprise, then, that Zayas and

\footnotetext{
${ }^{60}$ Stephen Carter on "Finalizing Latino Literature," memorandum, Mar. 15, 1983, folder 9, box 5, HWMCR.

61“¿Qué Somos?” HWMCR, 4.

${ }^{62}$ ASPIRA Newsletter, “Washington Wins Primary!” Mar. 1983, folder 5, box 25, HWMCR.

63"Linked fate" originates from political scientist Michael Dawson's pioneering work on African American political cohesion. See Michael C. Dawson, Behind the Mule: Race and Class in African American Politics (Princeton, NJ, 1994).

64“Fallece Luis Rossi, quien fue publisher clave y amigo entrañable de La Raza," La Raza, Dec. 27, 2019, https:// laraza.com/2019/12/27/fallece-luis-rossi-quien-fue-publisher-clave-y-amigo-entranable-de-la-raza/ (accessed Aug. 13, 2021).
} 
Rossi framed the "Latino vote" as a cohesive bloc with the power to swing the election. "The whole nation has its eyes on Chicago," reads a half-minute radio spot, "... the future of the Democratic Party and the relationships among the minority groups will be determined by the April 12th election in Chicago. The Latino vote has been identified as one of the determining factors in this fight." 65

Zayas developed a media strategy that emphasized the urgency of a unified Latino vote, and that engaged in more complex messaging around racial identity. More sensitive conversations of this nature took center stage in a bilingual periodical called El Independiente (The Independent). This newspaper aimed to provoke serious dialogue in Latino neighborhoods about racial self-identification. As one article argued, "It is ironic that some Hispanics do not want to admit that we are a discriminated minority, and foolishly and stubbornly insist on 'Anglicizing' themselves by associating with racist elements and practicing racism against Afro-Americans." ${ }^{66}$ Yet the paper was not merely a progressive voice; it was actually an in-house publication funded by the campaign - a unique and innovative strategy created to overcome the space and coverage limitations of traditional newspapers. El Independiente allowed the campaign to showcase the Black candidate's agenda for Latinos and broadened the coverage in Spanish-language print media. Much like the rest of the campaign, the newspaper stressed that Latinos were not just another assimilable white ethnic group.

Latinos for Washington events during the general campaign also contributed to the message of panethnic unity and interracial coalition building. Events ranged from intimate receptions for groups like the Hispanic Lawyers Committee for Washington to large-scale events such as the Latino endorsement rally held on March 18 at the Midland Hotel "comprised of Latinos who supported Daley and Byrne" ready to back the Democratic nominee. ${ }^{67}$ Washington's campaign effectively broke the mold of ethnic politics by bringing together national origin groups and leaders across ethnic lines, bridging the divide between Mexican and Puerto Rican neighborhoods. The "Song of the People" fundraiser, for example, featured works from an array of Latino artists. Hosted by the "voceros de la comunidad" ["spokesmen of the community"] Juan Velázquez, "Cha-Cha” Jiménez, Rudy Lozano, and Juan Solíz-the first two men Puerto Rican and the latter two Mexican-the event constituted an intentional celebration of equal representation. ${ }^{68}$

Nationally recognized Latino figureheads reinforced local leaders' panethnic appeals. An early proposal for Latino campaign surrogates consisted of flying in members of the Congressional Hispanic Caucus such as Bob Garcia and Edward Roybal, as well as celebrities like Erik Estrada, Vicki Carr, and Rita Moreno. ${ }^{69}$ The Latino Operations Department ultimately worked within the limited confines of its budget and made the necessary arrangements for a two-day joint visit by Grace Montañez Davis and Herman Badillo. Davis was the first Mexican American woman to serve as deputy mayor of Los Angeles and co-founded the Mexican American Political Association. Badillo was a New York politician and the first Puerto Rican elected to the United States Congress. The pair's itinerary included radio talks, grassroots campaigning, a dinner with Latino leaders, and a public townhall forum on "Latino unity."70 Their visit sought to project Mexican-Puerto Rican political unity and underscored the stakes of the 1983 election not only in Chicago, but also in the upcoming 1984 presidential race.

\footnotetext{
${ }^{65}$ Rossi Advertising for Washington, radio script, Mar. 21, 1983, folder 9, box 26, HWMCR.

${ }^{66}$ Emilio Pantojas García, "Washington, Latinos and Racism," El Independiente, Apr. 5, 1983, 5, box 21, RLP.

${ }^{67}$ Latino Endorsement Session, briefing notes, Mar. 18, 1983, folder 17, box 25, HWMCR.

68“Canto del Pueblo - Song of the People," flyer, Apr. 3, 1983, folder 16, box 11, HWMCR.

69"Restructuring for Victory," Bill Zayas to Peter Earle, note, Mar. 4, 1983, folder 9, box 5, HWMCR. Visits from national Latino leaders and celebrities was also a strategy employed by Democratic campaigns at the federal level, with notable visits to the Midwest during 1960 presidential election. See García, Viva Kennedy, 85-103.

${ }^{70}$ Herman Badillo and Grace Montañez Davis Itinerary, Mar. 19-20, 1983, folder 16, box 11, HWMCR.
} 
A visit to Chicago from New Mexico Governor Toney Anaya was the campaign's highestprofile Latino outreach event. The Mexican American governor agreed to be the keynote speaker for Harold Washington's "Hispanic Unity Dinner" on April 2, 1983, an event that brought in hundreds of supporters and thousands of dollars. A month before touching down in Chicago, Anaya had already called the city's Latino voters to action in a Spanish-language opinion piece for the Chicago Sun-Times entitled "Latinos: Es Hora de Aliarse" ["Latinos: It's Time to Unite"]. The op-ed foregrounded the panethnic unity rhetoric that he later emphasized during the visit. "There is great diversity among Latinos," he wrote, "... I commit myself to unify the Latinos of this country so that our political presence may be felt." For Anaya, just as for other Washington supporters like San Antonio Mayor Henry Cisneros and New York Congressman Bob Garcia, this public endorsement was rooted in a belief that Chicago's election had implications for the future, national viability of the Latino vote. $^{71}$

At the dinner, Anaya and Washington emphasized the connection between a unified Latino vote and a non-white minority identity. "As the nation's highest elected Hispanic," Anaya asserted, "I am urging all Latinos to unify behind Harold Washington because only through him can we reverse some of the terrible injustices that have been done against Hispanics." ${ }^{, 72}$ By framing bread and butter issues such as equal employment, electoral representation, and bilingual education as "injustices," Anaya prompted his audience to embrace a minority rights-based identity rooted in a civil rights struggle against oppression. The Governor's remarks also aligned neatly with Latinos' policy priorities at the national level during the 1980s, which Anaya hoped would unite Latinos in Chicago. ${ }^{73}$ Washington thanked Anaya for his support and reminded the audience that he could serve Latino needs only if he won their vote. "The Latino community has the potential to be a critically important swing vote," Washington said. "The Latino vote is key to winning this election."

Despite the Washington campaign's extensive effort to court Latino voters, controversies during the final stretch posed serious doubts about the prospect of Latino unity. Juan Andrade, Jr., director of the Midwest Voter Registration Education Project and the leading authority on Latino voters in Chicago, expressed skepticism: "The Hispanic vote is still a political wild card." 75 One example of the significant resistance to Harold Washington includes the case of Chicago Public School Board President Raul Villalobos, who endorsed incumbent Jane Byrne during the primary, but withheld his general election endorsement with the empty excuse that he was "exploring and waiting to see if there is a commitment to Hispanics on the part of either candidate." ${ }^{76}$ Villalobos's reticence clearly reflected his distrust of a Black mayor because the only other candidate, Bernard Epton, had no Latino policy platform whatsoever. ${ }^{77}$ In cases like these, anti-Black sentiment rooted in loyalty to the Machine explains

\footnotetext{
${ }^{71}$ Author's translation of "Hay mucha diversidad entre los hispanos ... Me propongo unificar a los latinos de este pais para que nuestra presencia politica se sienta." Toney Anaya, "Latinos: Es Hora de Aliarse," Chicago Sun-Times, Mar. 11, 1983, folder 28, box 36, HWMCR; Latino Endorsement List, Apr. 1983, folder 17, box 25, HWMCR.

${ }^{72}$ Roy Larson and Lillian Williams, "Washington Makes Pledges to Hispanics," Chicago Sun-Times, Mar. 29, 1983, folder 28, box 36, HWMCR.

${ }^{73}$ Rodolfo O. De la Garza, Public Policy Priorities of Chicano Political Elites (Washington, D.C., 1982); Jaime Raigoza, "U.S. Hispanics: A Demographic and Issue Profile," Population and Environment 10, no. 2 (Winter 1988): 95-106.

${ }^{74}$ Congressman Harold Washington to Hispanic Unity Dinner, remarks, Apr. 2, 1983, folder 15, box 11, HWMCR.

${ }^{75}$ Joye Brown, “City Hispanics Hold 'Swing' Vote,” Chicago Tribune, Mar. 24, 1983, A3.

${ }^{76}$ Author's translation of "Estamos explorando y estamos tratando de ver si hay un acercamiento a los hispanos de parte de los dos candidatos." "Washington Promete Trabajos a Hispanos," El Mañana, Mar. 29, 1983, 4, folder 28, box 36, HWMCR.

${ }^{77}$ Epton did not have a specific Latino platform and had limited outreach in Latino neighborhoods generally. Tony Roque, a political aide to Cook County Democratic Chairman Edward Vrdolyak and former president of
} 
Latino opposition to Washington in the absence of a competing Latino platform or outreach program from Epton.

Harold Washington's refusal to endorse Mexican American aldermanic candidate Ray Castro drew further Latino opposition. Castro served as the Seventh Ward Democratic Committeeman and was a candidate for alderman in the general election runoff against a Black opponent named William Beavers. Just four days before the general election, an explosive article in the Daily Calumet asserted that Castro's precinct captains called for an "open revolt" against Washington because he did not formally endorse Castro at a rally in the Seventh Ward. This confirmed observers' suspicions that a Black mayor would sideline Latino interests. "If Washington doesn't have the nerve to endorse one Hispanic," argued Castro staffer Sara Reyes, "then what do we have to expect when, and if, he becomes mayor?"78 Though Washington ultimately endorsed Beavers, he did not take this or any other endorsement lightly, knowing the distrust it might provoke. ${ }^{79}$ In fact, a televised Washington advertisement featured white alderman Larry Bloom talking about how Washington endorsed him over six Black candidates, proving that "he's got no favorites, he's got no hidden agenda," and no preferential treatment toward Blacks. ${ }^{80}$

National media outlets focused on Chicago's Latino voters the day before the general election. On April 11, an article in USA Today centered Latinos in its analysis of the Chicago mayor's race as the pivotal swing vote that was still heavily divided. "Hispanics could tip the scales," the article argued, but their influence was said to be split by nationality wherein "Puerto Ricans favor Washington; Mexicans, Epton." ${ }^{81}$ That same day, the New York Times noted the extensive efforts by the Washington campaign to court Latino voters, while also reiterating the debate between Latinos "on whether they should view themselves as white or as a minority group." Of course, the logic of race-based resource competition between Latinos and Blacks, which Washington so desperately sought to counter, endured. As local social services coordinator Christina Quintana told the Times, most Latinos she worked with supported Washington, but many still feared "Washington might fill all of the city jobs with blacks." 82

Almost 1.3 million people voted in Chicago on April 12, 1983. Harold Washington won a narrow victory with 51.7 percent of the vote and became Chicago's first Black mayor. Epton earned a shocking 48 percent of the vote, the most won by a Republican since 1927 and 200,000 more votes than the last three GOP mayoral candidates combined. ${ }^{83}$ Ultimately, a racial divide sharply polarized Black and white voters-a divide that Latinos awkwardly straddled (Table 2). Though Washington won 75.3 percent of Latino votes, this majority support was stratified by national origin. Puerto Rican areas like the Thirty-First Ward overwhelmingly sided with Washington. Mexican American wards marginally leaned in Washington's favor, more than Cubans but to a lesser degree than Puerto Ricans. Rudy Lozano's Twenty-Second Ward, which encompassed the largest Mexican population paired with a robust IPO, was still the only district that Washington won with less than 60 percent of the vote and proof

the Steelworkers Union in South Chicago, was one of the only Latinos working for the Epton campaign. According to Alkalimat and Gills, "Epton never went into the Black community and, except for a few instances, did not attempt to attract the Latino vote." David Axelrod and Thom Shanker, "Vrdolyak Aide Organizing Voters for Epton," Chicago Tribune, Mar. 29, 1983; Alkalimat and Gills, "Black Power vs. Racism,” 129.

${ }^{78}$ John Kass, "Hispanics Angry at Washington, Call for Revolt," Chicago Daily Calumet, Apr. 8, 1983, folder 28, box 36, HWMCR.

${ }^{79}$ Fremon, Chicago Politics, 60.

80"Mayoral Spots," Image Union, episode 608, dir. Don Voigt, prod. Tom Weinberg, WTTW Chicago, Jan. 3, 1984, https://mediaburn.org/video/image-union-episode-608/?t=20:36/ (accessed Aug. 13, 2021).

${ }^{81}$ Jeffrey Stinson and Tom Schafer, "Keys to Chicago: Turnout, Hispanics," USA Today, Apr. 11, 1983, 3A.

${ }^{82}$ Nathaniel Sheppard Jr., "Hispanic Vote Seen as a Key in Chicago Mayoral Race," New York Times, Apr. 11, 1983, B8.

${ }^{83}$ Paul M. Green, “Chicago Election: The Numbers and the Implications," Illinois Issues, Aug. 1983, 13-8, here 17, https://www.lib.niu.edu/1983/ii830813.html (accessed Aug. 13, 2021). 
Table 2. Chicago general election mayoral results by race/ethnicity, 1983

\begin{tabular}{llc}
\hline Race/ethnicity & Washington & Epton \\
\hline White & $12 \%$ & $86 \%$ \\
\hline Black & $98 \%$ & $2 \%$ \\
\hline Latino & $75.3 \%$ & $19 \%$ \\
\hline Cuban & $48.2 \%$ & $37 \%$ \\
\hline Mexican & $62.7 \%$ & $30.6 \%$ \\
\hline Puerto Rican & $82.3 \%$ & $12.8 \%$ \\
\hline
\end{tabular}

Source: Juan Andrade, Jr. and Wilfredo Nieves, Final Exit Poll Report, Chicago Mayoral Election, April 12, 1983 (Columbus, OH, 1983), 4-10; Alkalimat and Gills, "Black Power vs. Racism," 148-50.

positive of Mexicans' unresolved identity politics. ${ }^{84}$ In the end, the uneven Latino support for Washington revealed the variance of anti-Blackness across national origin subgroups and their ongoing struggle to solidify panethnic political unity.

When compared to the unity of the Black vote, the Latino bloc that appeared at the polls was far from the Latino landside expected for the "rainbow coalition" candidate. Not only did onequarter of Latino votes go to the Republican candidate, many more Latinos stayed home altogether. Compared to a record-high turnout rate of 81 percent across all voters, about 40 percent of registered Latino voters did not go to the polls. The persistence of anti-Black sentiment likely contributed to lower turnout in the form of boycotting Washington, as suggested in the minutes of a "Hispanic political roundtable" from early March. The roundtable was composed of moderate Mexican American leaders and supporters of Mayor Byrne during the primary. According to the Washington campaign's invited envoy Peter Earle, the meeting's discussion focused on the stance that "Latinos should exercise a demonstration of potential political power by boycotting the election." ${ }^{85}$ Whether a boycott or just apathy, Latinos severely underperformed as an equal partner in the Black-Latino coalition of 1983.

Existing interpretations of the 1983 election speak of Harold Washington's unifying impact on Latinos, referring to his candidacy as "the spark that ignited electoral participation," "a turning point for Latino political empowerment," and "a milestone ... for black-Latino relations." 66 Granted, Latinos engaged more in electoral politics after 1983, but their unity, in relation to each other and to Blacks, stalled and worsened. Latino voters were once again divided as Mayor Washington faced Jane Byrne in a two-way race during the 1987 Democratic primary. Polling by the Chicago Tribune found again that "many Hispanics believe the mayor has given them short shrift while he concentrates on improving conditions for blacks." ${ }^{87}$ Latino support in the 1987 primary signaled prevalent distrust of a Black mayor, but Washington narrowly edged by with 55 percent of the Latino vote to Byrne's 45 percent. ${ }^{88}$ White backlash resulted

\footnotetext{
84“Election Results for 1983 General Election, Mayor, Chicago, IL," Chicago Democracy Project, http://chicagodemocracy.org/ElectionResults.jsp?election=crdd_general,crdd_1983_general_election,il_chi_mayor (accessed Aug. 13, 2021); Fremon, Chicago Politics, 150.

${ }^{85}$ Peter Earle, notes from Hispanic Political Roundtable, Mar. 7, 1983, folder 11, box 4, HWMCR.

${ }^{86}$ Córdova, "Harold Washington and the Rise of Latino Electoral Politics in Chicago," 33; Mantler, "Rainbow Reformers," 232; Opie, Upsetting the Apple Cart, 142.

${ }^{87}$ John Camper, "Hispanics Receptive to Byrne’s Advances," Chicago Tribune, Jan. 6, 1987, A1. Other news outlets similarly viewed Latinos as a tossup swing vote in 1987. For instance, see Kevin Klose, "Racial Issue Flares in Chicago Primary," Washington Post, Feb. 8, 1987, A6.

${ }^{88}$ Nick Panagakis, “The Pulse: Mayor Washington's Consistent Constituency,” Illinois Issues, May 1987, 36-8, here 37, https://www.lib.niu.edu/1987/ii870536.html (accessed Aug. 13, 2021).
} 
in another contentious general election with the third-party candidacy of Democratic Party chairman Edward Vrdolyak. In the end, Washington reconsolidated his tenuous coalition in 1987 with 77 percent of Latino votes and 54 percent of the total electorate. ${ }^{89}$

Harold Washington's sudden death in 1987 and the scramble to elect a replacement further complicated the ongoing debate about Latinos' precarious position along the Black/white political divide. The 1989 special election between white candidate Richard M. Daley and Black candidate Timothy Evans, however, confirmed Latinos' decisive racial-political alignment with whites. While many believed the Latino community would join Blacks in supporting Evans as Washington's legacy, most Latinos staked their future on the old Machine's heir. This was certainly the case for Puerto Rican alderman Luis Gutiérrez, who, despite having been mentored by Harold Washington, endorsed Daley for mayor. Labeled a "defector" and "traitor" by progressive Latino leaders, Gutiérrez's defection from the rainbow coalition was in fact a precursor to the white-Latino electoral coalition that kept the new Daley Machine in office for twenty-two years. ${ }^{90}$ Latinos decisively "calculated that there is more to be gained by supporting a White Mayor than a Black Mayor," and their consistent majority support in Daley's re-election campaigns underscored Latino voters' enduring misgivings about Black political leadership. ${ }^{91}$

Exposing the influence of anti-Black sentiment on Latino political behavior reveals the underappreciated importance of primary elections. Latinos actively preferred white primary candidates Byrne and Daley in 1983, but an even greater opposition to hard-line, conservative Republicanism outweighed and masked these preferences in the general election. Scholars' neglect of the primary contest, as well as disproportionate focus on general election results, help to explain why anti-Blackness has been inadequately addressed in previous studies of the 1983 election. Similarly, Democratic presidential nominee Barack Obama's majority share of the Latino vote (67 percent) in the 2008 U.S. general election quickly overshadowed the fact that Latinos voted for white candidate Hillary Clinton over Obama at a rate of two-to-one in the Democratic primaries. ${ }^{92}$ Despite espousing racial resentment on par with whites, Latino opposition to both Washington and Obama in primary elections still allowed the Black candidates to win the majority of the Latino vote against Republican candidates. ${ }^{93}$ Primary elections, then and now, thus merit more careful attention as sites of anti-Blackness in electoral politics before party loyalty overrides it.

Popular understandings of the 1983 Chicago mayoral election also emphasize the majority Latino support behind Harold Washington in the general election, without mention of earlier divisions. As Rudy Lozano's life gave us insight to this historical moment, his death is our guide

\footnotetext{
${ }^{89}$ Jean Latz Griffin and Manuel Galvan, "Hispanics Tighten Political Coalition," Chicago Tribune, Apr. 10, 1987, A4.

${ }^{90}$ Jorge Casuso and Ben Joravsky, “El Gallito': Luis Gutierrez Carves a Major Role for Himself in Chicago Politics," Chicago Tribune, June 4, 1989, 20; Cruz, City of Dreams, 121.

${ }^{91}$ Dick Simpson and Tom M. Kelly, "The New Chicago School of Urbanism and the New Daley Machine," Urban Affairs Review 44, no. 2 (Nov. 2008): 218-38, here 234.

${ }^{92}$ The Latino vote in the 2008 Illinois Democratic primary was more favorable for Obama than the national average, with Latinos equally divided between Clinton ( 49 percent) and Obama (50 percent). Even Obama's home-state advantage did not win him a clear majority of Latino support in Illinois. Susan Minushkin and Mark Hugo Lopez, “The Hispanic Vote in the 2008 Democratic Presidential Primaries," Pew Hispanic Center, June 4, 2008, https:// www.pewresearch.org/hispanic/2008/03/07/the-hispanic-vote-in-the-2008-democratic-presidential-primaries/ (accessed Aug. 13, 2021); Mark Hugo Lopez, “The Hispanic Vote in 2008," Pew Hispanic Center, Nov. 7, 2008, https://www.pewresearch.org/hispanic/2008/11/05/the-hispanic-vote-in-the-2008-election/ (accessed Aug. 13, 2021).

${ }^{93}$ Segura and Valenzuela confirm that Latinos' anti-Black sentiment did not impact their established party preferences during the 2008 presidential general election, even though similar levels of racial resentment did skew whites' partisanship more toward the Republican Party. Gary M. Segura and Ali A. Valenzuela, "Hope, Tropes, and Dopes: Hispanic and White Racial Animus in the 2008 Election," Presidential Studies Quarterly 40, no. 3 (Sept. 2010): 497-514, here 512.
} 
to the persistent mythos regarding Black-Latino unity. Lozano was killed in his home in June of 1983 at the age of thirty-one, just two months into Harold Washington's first term. ${ }^{94}$ The motive behind Lozano's murder remains unknown, but progressive community organizations and publications quickly settled on politically motivated assassination, making Lozano a political martyr of the Washington campaign's rainbow coalition. The $7^{\text {th }}$ Ward Independent, for example, speculated that "behind Rudy's murder stand economic and political interests who feared the Black-Latino-Poor White alliance he was helping to build around the Washington campaign." 95 The tragedy made headlines as thousands marched in honor of the deceased activist and paid their respects at his funeral.

A newly inaugurated Mayor Washington joined the mourners and declared that "if the coalition of Chicago which came with my election is due to anyone, it is due to Rudy Lozano." ${ }^{\text {"In }}$ addition to Mexicans, Puerto Rican community leaders also turned to Lozano's legacy as evidence of Latino panethnic unity. Speaking to Spanish-language newspaper El Mañana, Reverend Jorge Morales lauded the fallen activist on the one-year anniversary of his death. "Rudy was not Puerto Rican," Morales said, "but he won the respect of the community through his commitment to our struggles." $"$ Lozano was continuously memorialized in death, especially by the Twenty-Second Ward Independent Political Organization, which regularly dedicated its yearly conventions in his honor. As Chicago journalist Jorge Casuso summarized in 1986, "Lozano has become more important to the Hispanic community in death than in life." 98 Washington soon joined the pantheon of the rainbow coalition and was venerated in similar fashion when he died of a heart attack in 1987, shortly into his second term.

To this day, progressive leaders hearken to the memory of Washington and Lozano's partnership as the consummate model for Black-Latino political unity, as illustrated by the career of U.S. Representative Jesus "Chuy" Garcia. Close friends with Rudy Lozano, Garcia entered the world of Chicago politics through the independent political movement and went on to serve in elected positions at the local, state, and, currently, federal levels. In 2015, Garcia sought to rekindle the Washington coalition as a candidate for mayor and forced the first mayoral runoff in Chicago's history against incumbent Mayor Rahm Emanuel. Garcia's 2015 campaign literature and rhetoric emphasized his connection to Washington and the early independent movement, with frequent invocations to the rainbow coalition of the 1980s. Mainstream media outlets also framed Garcia's bid as a modern-day iteration of Washington and Lozano's coalition. 99 "With Chuy running," said Lozano's surviving widow Lupe, "it's like a spirit of Rudy

\footnotetext{
${ }^{94}$ Rivlin, "Who Killed Rudy Lozano?" 1, RLP.

${ }^{95}$ The 7 th Ward Independent, July 1983, 1, folder 8, box 1, RLP.

${ }^{96}$ Joseph A. Reaves and Jerry Thornton, “Unity, Tears Mark Mass for Lozano," Chicago Tribune, June 14, 1983, 11.

${ }^{97}$ Author's translation of "Rudy no era puertorriqueño, pero se ganó el respeto de la comunidad por su compromiso con las luchas de nosotros." Antonio Zavala, "Se Recuerda a Rudy Lozano a Un Año de su Muerte," El Mañana, June 8, 1984, 2, box 21, RLP.

${ }^{98}$ Jorge Casuso, “Ojos y Oidos Column: Lozano myth unfair to Lozano the man," Chicago Free Press, June 1986, folder 37, box 4, RLP.

${ }^{99}$ Steve Bogira, “The Mayoral Race and the Color of Inequality in Chicago," Chicago Reader, Mar. 31, 2015, https://www.chicagoreader.com/Bleader/archives/2015/03/31/the-mayoral-race-and-the-color-of-inequality-in-chicago (accessed Aug. 13, 2021); Julie Bosman, "Ethnic Rivalries in Chicago Race: A Mayoral Candidate Struggles to Unite Latinos and Blacks," New York Times, Apr. 4, 2015, A10; Evan Garcia, "Rev. Jesse Jackson and Black Ministers Endorse Garcia for Mayor,” WTTW, Mar. 10, 2015, https://news.wttw.com/2015/03/10/rev-jesse-jackson-and-black-ministers-endorse-garc-mayor (accessed Aug. 13, 2021); Edward McClelland, "Rahm Emanuel's Political Nightmare: Jesus ‘Chuy’ Garcia Tells Salon Why He'll Oust the Mayor,” Salon, Mar. 4, 2015, https:// www.salon.com/2015/03/04/rahm_emanuels_political_nightmare_jesus_chuy_garcia_tells_salon_why_hell_oust_the_mayor/ (accessed Aug. 13, 2021); Salim Muwakkil, “The Barriers to Black-Brown Unity,” In These Times, Jan. 29, 2015, https://inthesetimes.com/article/the-barriers-to-black-brown-unity (accessed Aug. 13, 2021); John Nichols, "Chicago's Chuy Garcia Lost an Election, but Won a Movement," Nation, Apr. 8, 2015, https://www.thenation.com/article/archive/chicagos-chuy-garcia-lost-election-won-movement/ (accessed Aug. 13, 2021); Michael
} 
that keeps living on." ${ }^{\prime 00}$ Though Garcia ultimately lost the election and barely unified 66 percent of Latino voters, his candidacy was a testament to the staying power of 1983's political memory.

This reappraisal of the rainbow coalition narrative has sought to complicate the romanticized interpretation of the 1983 election prevalent in academic and popular accounts, identifying what one scholar has called the "cracks in the rainbow." 101 As we have seen, Latino support for Harold Washington was stratified, anomalous, and fleeting from the very beginning-a fact obscured by the rose-colored glasses of memory that have overemphasized panethnic and interracial unity. In June 2020, the American Historical Association released a statement that called on historians to "confront this nation's past" through our work, a response to the ongoing crisis of police brutality against African Americans that also applies here. ${ }^{102}$ Cases like the 1983 Chicago mayoral election demonstrate that anti-Blackness was, and continues to be, a fundamental aspect of modern urban politics. Confronting the past in this instance requires us to begin difficult and uncomfortable conversations about Latino history, identity, and politics that acknowledge both the inspirational coalitions as well as deep-seated racial resentment. Ultimately, the vision of unity articulated by Lozano and Washington will remain tenuous as long as the necessary reminders of Latino disunity are few and far between.

Moments of disunity during the 1983 election have much to teach us when we apply political scientist Cristina Beltrán's reimagining of Latino panethnicity as a verb rather than a label. “Subjects marked 'Latino' do not represent a preexisting community just waiting to emerge from the shadows," Beltrán argues. "Instead, 'Latino politics' is best understood as a form of enactment, a democratic moment in which subjects create new patterns of commonality and contest unequal forms of power." ${ }^{103}$ In this way, we must not confuse 1983 as confirmation of a primordial Latino unity or the natural partnership between Blacks and Latinos. Instead, Latino politics, then and now, calls for deliberative consensus building and constant selfinterrogation. Latino Chicagoans' vigorous debate about their racial identity and their relationship to each other is a case study in this messy practice of Latinidad-a history that reminds us that Latino panethnicity must be continually questioned, developed, and remade.

Jaime Sánchez, Jr. is a doctoral candidate in the Department of History at Princeton University, USA, with a focus on modern U.S. politics, race, and ethnicity. He is currently working on a history of the Democratic National Committee centered around the political incorporation of historically underrepresented groups.

Romain, "Harold 2.0?” Austin Weekly News, Mar. 10, 2015, https://www.austinweeklynews.com/2015/03/10/harold2-0/ (accessed Aug. 13, 2021); Sean Sullivan, "Chicago Mayor's Race Is Dividing City's Black Community," Washington Post, Mar. 15, 2015, A6.

${ }^{100}$ Hal Dardick and Bob Secter, "Jesus 'Chuy' Garcia Hopes to Rekindle Harold Washington Torch at City Hall," Chicago Tribune, Feb. 11, 2015, https://www.chicagotribune.com/politics/ct-jesus-chuy-garcia-chicago-mayor-met0211-20150211-story.html (accessed Aug. 13, 2021).

${ }^{101}$ Karen M. Kaufmann, "Cracks in the Rainbow: Group Commonality as a Basis for Latino and African-American Political Coalitions,” Political Research Quarterly 56, no. 2 (June 2003): 199-210.

102"Confronting a Sordid History of Racist Violence in the United States," American Historical Association, June 2020, https://www.historians.org/Documents/News\%20and\%20Advocacy/Racist\%20Violence\%20Statement.pdf/ (accessed Aug. 13, 2021).

${ }^{103}$ Beltrán, The Trouble with Unity, 157. 